\title{
Cadmium exposure enhances cell migration and invasion through modulated TRPM7 channel expression
}

\author{
Alison Vanlaeys ${ }^{1}$. Grégory Fouquet ${ }^{1} \cdot$ Philippe Kischel $^{1} \cdot$ Frédéric Hague $^{1} \cdot$ Sylvie Pasco-Brassart ${ }^{2}$. \\ Thibaut Lefebvre ${ }^{1}$. Pierre Rybarczyk ${ }^{1,3} \cdot$ Isabelle Dhennin-Duthille ${ }^{1} \cdot$ Bertrand Brassart $^{2}$. \\ Halima Ouadid-Ahidouch ${ }^{1} \cdot$ Mathieu Gautier $^{1}$ (B)
}

Received: 2 September 2019 / Accepted: 11 February 2020 / Published online: 20 February 2020

(c) The Author(s) 2020

\begin{abstract}
Cadmium is a xenobiotic involved in neoplastic transformation. Cadmium enters the cells through divalent cation transporters including the Transient Receptor Potential Melastatin-related 7 (TRPM7) which is known to be involved in cancer cell fate. This work aimed to study the role of TRPM7 in neoplastic transformation induced by cadmium exposure in non-cancer epithelial cells. Non-cancer epithelial cells were chronically exposed to low-dose of cadmium. TRPM7 expression and function were studied by Western-Blot, Patch-Clamp and calcium and magnesium imaging. Finally, cell migration and invasion were studied by Boyden chamber assays. Chronic cadmium exposure induced TRPM7 overexpression and increased the membrane currents $(P<0.001)$. Cells exposed to cadmium had higher intracellular calcium and magnesium levels $(P<0.05)$. TRPM7 silencing restored calcium levels but strongly decreased intracellular magnesium concentration $(P<0.001)$. Moreover, cadmium exposure enhanced both cell migration and invasion, but TRPM7 silencing strongly decreased these features $(P<0.001)$. Furthermore, mammary epithelial cells exposed to cadmium became rounded and had less cell-to-cell junctions. Cadmium exposure decreased epithelial markers while the mesenchymal ones were increased. Importantly, TRPM7 silencing was able to reverse these phenotypic modifications $(P<0.05)$. To summarize, our data show that chronic cadmium exposure enhanced TRPM7 expression and activity in non-cancer epithelial cells. TRPM7 overexpression induced intracellular magnesium increase and stimulated cell migration and invasion. These neoplastic properties could be linked to a TRPM7dependent epithelial-to-mesenchymal transition reprogramming in cell exposed to cadmium. These findings provide new insights into the regulation of cell fates by cadmium exposure.
\end{abstract}

Keywords Cadmium $\cdot$ TRPM7 $\cdot$ Magnesium $\cdot$ Cell invasion $\cdot$ EMT

Abbreviations
$\begin{array}{ll}\mathrm{BCA} & \text { Bicinchoninic acid } \\ \mathrm{Ca}^{2+} & \text { Calcium }\end{array}$

Electronic supplementary material The online version of this article (https://doi.org/10.1007/s00204-020-02674-w) contains supplementary material, which is available to authorized users.

Mathieu Gautier

mathieu.gautier@u-picardie.fr

1 Laboratoire de Physiologie Cellulaire et Moléculaire - UR UPJV 4667, UFR Sciences, Université de Picardie Jules Verne (UPJV), 80039 Amiens, France

2 UMR CNRS 7369 Matrice Extracellulaire et Dynamique Cellulaire (MEDyC), Université de Reims Champagne Ardenne (URCA), 51095 Amiens, France

3 Anatomie et Cytologie Pathologiques, $\mathrm{CHU}$ Amiens-Picardie, Amiens, France

$\begin{array}{ll}\mathrm{Cd}^{2+} & \begin{array}{l}\text { Cadmium } \\ \text { DMEM/F-12 }\end{array} \\ \text { Dulbecco's modified Eagle's medium/ } \\ \text { nutrient mixture F-12 } \\ \text { EDTA } & \begin{array}{l}\text { Dimethyl sulfoxide } \\ \text { Ethylenediaminetetraacetic acid }\end{array} \\ \text { EGTA } & \text { Ethylene glycol-bis( } \beta \text {-aminoethyl ether)- } \\ & N, N, N^{\prime}, N^{\prime} \text {-tetraacetic acid } \\ \text { EMT } & \text { Epithelial-to-mesenchymal transition } \\ \text { ER } & \text { Estrogen receptor } \\ \text { FCS } & \text { Fetal calf serum } \\ \text { Mg } & \text { Magnesium } \\ \text { Mn }{ }^{2+} & \text { Manganese } \\ \text { MIC } & \text { Magnesium inhibited cation } \\ \text { MTT } & 3-(4,5-D i m e t h y l-2-t h i a z o l y l)-2,5-d i p h e n y l- \\ & 2 \text {-tetrazolium bromide } \\ \text { SDS } & \text { Sodium dodecyl sulfate } \\ \text { siControl } & \text { Scrambled small interfering RNA }\end{array}$


siTRPM7 Small interfering RNA targeting TRPM7

TRPM7 Transient receptor potential melastatinrelated 7

$\mathrm{Zn}^{2+} \quad$ Zinc

\section{Introduction}

Cadmium $\left(\mathrm{Cd}^{2+}\right)$ is a metal pollutant prone to bioaccumulation, mainly in the liver and in the kidney (Chen et al. 2019; Rani et al. 2014). The major sources of $\mathrm{Cd}^{2+}$ exposure for humans are the cigarette smoke and contaminated drinking water and/or food. $\mathrm{Cd}^{2+}$ is considered as a class I human lung carcinogen since 2004 (Waalkes 2003). Moreover, $\mathrm{Cd}^{2+}$ accumulation in tissues is suspected to be linked to breast cancer development (Larsson et al. 2015). In vivo studies showed that a single intraperitoneal dose of $\mathrm{Cd}^{2+}(\sim 27 \mathrm{nmol} /$ $\mathrm{kg}$ ) mimics estrogens leading to both endometrial and mammary gland hyperplasia and hypertrophy in ovariectomized female rats (Johnson et al. 2003). Moreover, $\mathrm{Cd}^{2+}$ stimulates MCF7 breast cancer cell proliferation through estrogen receptor (ER) activation (Martinez-Campa et al. 2006). In several breast cancer cell line models, $\mathrm{Cd}^{2+}$ potentiates the interaction between ER and c-Jun leading to the stabilization of this transcription factor complex and its recruitment to the promoters of cyclin D1 and c-myc (Siewit et al. 2010). Thus, $\mathrm{Cd}^{2+}$ has been defined as a metalloestrogen, an endocrine disrupter able to promote the development of estrogendependent cancers (Darbre 2006). However, chronic $\mathrm{Cd}^{2+}$ exposure can also induce non-cancer epithelial cell transformation into a highly invasive phenotype independently of ER expression (Benbrahim-Tallaa et al. 2009; Qu et al. 2012), suggesting that $\mathrm{Cd}^{2+}$ acts as a carcinogen through an alternative mechanism that do not involve estrogen receptors. $\mathrm{Cd}^{2+}$ can diffuse across the plasma membrane through several transporters including ion channels (Thevenod 2010). Among them, TRPM7 is a non-selective channel, mainly permeant to $\mathrm{Mg}^{2+} / \mathrm{Ca}^{2+}$ ions and also permeant to other divalent cations including $\mathrm{Cd}^{2+}$ (Monteilh-Zoller et al. 2003). It has been recently shown that TRPM7 is the main gatekeeper for $\mathrm{Zn}^{2+}, \mathrm{Mg}^{2+}$ and $\mathrm{Ca}^{2+}$ intestinal absorption (Mittermeier et al. 2019). TRPM7 is also involved in $\mathrm{Cd}^{2+}$ uptake, leading to cytotoxic accumulation in human osteoblasts. This latter uptake can possibly explain the occurrence of bone resorption and fracture following $\mathrm{Cd}^{2+}$ poisoning (Martineau et al. 2010). The low selectivity of TRPM7 towards divalent cations may also provide a favorite route for $\mathrm{Cd}^{2+}$ in epithelial cell leading to cell transformation into a neoplastic phenotype. Numerous studies have shown that TRPM7 is involved in cancer progression (Gautier et al. 2016). For instance, TRPM7 is overexpressed in breast cancer and this channel regulates MCF7 cell proliferation (Dhennin-Duthille et al. 2011; Guilbert et al. 2009).
Moreover, TRPM7 also regulates breast cancer cell migration and invasion in MDA-MB231 and MDA-MB-435S cell lines (Guilbert et al. 2013; Meng et al. 2013), as well as metastasis formation and dissemination in vivo in a mouse xenograft model (Middelbeek et al. 2012). The present study aims to assess the role of TRPM7 in the acquisition of an aggressive phenotype by non-cancer epithelial cells chronically exposed to cadmium.

\section{Material and methods}

\section{Cell culture and cadmium exposure}

We used two human non-cancer epithelial cell lines: one from breast (MCF10A), and one from pancreas (hTERTHPNE). MCF10A were purchased from ATCC $®$ (CRL$10317^{\mathrm{TM}}$ ) and were exposed with $2.5 \mu \mathrm{M} \mathrm{Cd}^{2+}$ for 40 weeks according to previously published data (BenbrahimTallaa et al. 2009). hTERT-HPNE were purchased by ATCC $®$ (CRL-4023 ${ }^{\mathrm{TM}}$ ) and exposed with $1 \mu \mathrm{M} \mathrm{Cd}^{2+}$ for 30 weeks (Qu et al. 2012). MCF10A were cultured in Dulbecco's Modified Eagle's Medium/Nutrient Mixture F-12 (DMEM/F-12) supplemented with 10\% Fetal Calf Serum (FCS), hydroxycortisone $(50 \mathrm{ng} / \mathrm{mL})$, insulin $(0.01 \mathrm{mg} / \mathrm{mL})$, human recombinant EGF $(20 \mathrm{ng} / \mathrm{mL})$, and cholera toxin $(100 \mathrm{ng} / \mathrm{mL})$. hTERT-HPNE were cultured in base medium: 75\% DMEM without glucose (Sigma) and 25\% Medium M3 Base (Incell Corp) with 5\% FCS. Complete growth medium was supplemented with the following components: human recombinant EGF $(10 \mathrm{ng} / \mathrm{mL})$, D-glucose $(1 \mathrm{~g} / \mathrm{L})$, puromycin $(750 \mathrm{ng} / \mathrm{mL})$, L-glutamine $(0.3 \mathrm{~g} / \mathrm{L})$, and sodium bicarbonate $(1.5 \mathrm{~g} / \mathrm{L})$. Cells were trypsinized once a week using trypsin-EDTA (Sigma-Aldrich, Inc.) and incubated at $37^{\circ} \mathrm{C}$ in a humidified atmosphere containing $5 \% \mathrm{CO}_{2}$.

\section{Small interference RNA technique}

siRNAs were transfected in non-cancer cells by nucleofection using a Nucleofector ${ }^{\mathrm{TM}}$ II device (Lonza). MCF10A and hTERT-HPNE cells $\left(10^{6}\right.$ cells) were transfected with $2 \mu \mathrm{g}$ of siRNA according to the optimized protocol recommended by Lonza. Non-cancer cells were nucleofected with siRNA targeting TRPM7 (siTRPM7) or a scrambled siRNA (siControl) as previously described (Rybarczyk et al. 2017). All the experiments were performed $48 \mathrm{~h}$ following nucleofection.

\section{TRPM7 overexpression}

Zebrafish (ZF) TRPM7 was overexpressed in MCF10A cells by nucleofection $\left(10^{6}\right.$ cells, program X-005, kit L). MCF10A cells were transfected with $2 \mu \mathrm{g}$ pcDNA5-TO-ZF-WTTRPM7 (WT-TRPM7) or $2 \mu \mathrm{g}$ pcDNA5-TO as previously 
published (Guilbert et al. 2013). All experiments were performed $72 \mathrm{~h}$ after transfection.

\section{Western-blot}

Cells were lysed $30 \mathrm{~min}$ on ice in radioimmunoprecipitation assay buffer (1\% Triton X-100, $1 \%$ Na deoxycholate, $150 \mathrm{mM} \mathrm{NaCl}, 10 \mathrm{mM} \mathrm{PO} \mathrm{Na}_{2} / \mathrm{K}, \mathrm{pH}$ 7.2) supplemented with Sigma P8340 inhibitors cocktail, 2 mM EDTA, and $5 \mathrm{mM}$ orthovanadate. After centrifugation at 13,000 rpm, the proteins in the supernatant were quantified using the BCA method (BioRad). Equal amounts of each protein sample $(50 \mu \mathrm{g})$ were separated by electrophoresis on sodium dodecyl sulfate (SDS) polyacrylamide gel electrophoresis and blotted onto nitrocellulose membrane (Amersham). Blots were incubated with antibodies raised against TRPM7 (1/1000, Abcam), N-Cadherin (1/1000, Abcam), E-Cadherin $(1 / 1000$, Abcam), Vimentin (1/250, ThermoFisher) and Tubulin (1/7000, Sigma-Aldrich). Blots were developed with the enhanced chemiluminescence system using specific peroxidase-conjugated anti-IgG secondary antibodies.

\section{Electrophysiological recordings}

To study ion channel currents, we used the conventional patch-clamp technique (Hamill et al. 1981). TRPM7 currents recordings were performed using the whole-cell configuration as previously described (Rybarczyk et al. 2017). Briefly, membrane potential was held at $-40 \mathrm{mV}$, and currents were elicited by a ramp depolarization from $-100 \mathrm{mV}$ to $+100 \mathrm{mV}$ for $350 \mathrm{~ms}$. Interval between each ramp depolarization was $10 \mathrm{~s}$. After the dialysis of intracellular media by the free Mg intrapipette solution, the Magnesium Inhibited Cation (MIC) current was recorded (Prakriya and Lewis 2002). To measure the MIC current, the difference between the steady-state current activated by the depletion of $\left[\mathrm{Mg}^{2+}\right]_{\mathrm{i}}$ and the basal current recorded few minutes after patch rupture was calculated. Currents were expressed as current densities (in pA.pF ${ }^{-1}$ ) by dividing the current intensity (in $\mathrm{pA}$ ) by the cell capacitance (in $\mathrm{pF}$ ). All experiments were performed at room temperature.

\section{Manganese quenching and intracellular calcium and magnesium imaging}

Non-cancer cells were plated on glass coverslips in $35-\mathrm{mm}$ diameter dishes at a density of $3 \times 10^{4}$ and $5 \times 10^{4}$ cells for hTERT-HPNE and MCF10A, respectively. After $48 \mathrm{~h}$, cells were loaded in cell growth medium at $+37{ }^{\circ} \mathrm{C}$ for different times ( $35 \mathrm{~min}$ for hTERT-HPNE and $40 \mathrm{~min}$ for MCF-10A) with $3 \mu \mathrm{M}$ Fura-2 (Sigma-Aldrich) or $3 \mu \mathrm{M}$ Mag-Fura-2 (Invitrogen) and subsequently washed three times with the extracellular solution (in $\mathrm{mM}: \mathrm{NaCl} 145 ; \mathrm{KCl} 5$; HEPES
10; Glucose 5; $\mathrm{MgCl}_{2} 2 ; \mathrm{CaCl}_{2}$ as indicated; $\mathrm{MnCl}_{2}$ as indicated; $\mathrm{CdCl}_{2}$ as indicated; $\mathrm{pH}$ adjusted to 7.4 with $\mathrm{NaOH}$ ). The coverslip was then transferred onto a perfusion chamber on a Zeiss microscope equipped with fluorescence. Manganese $\left(\mathrm{Mn}^{2+}\right)$ is a cation able to fix Fura-2 fluoroprobe and to quench its fluorescence (Fasolato et al. 1993). To estimate the divalent cation influx, we used the $\mathrm{Mn}^{2+}$ quenching protocol as previously described (Rybarczyk et al. 2017). Briefly, cells were perfused for $1 \mathrm{~min}$ with the extracellular solution. Then, $\mathrm{Ca}^{2+}$ was replaced by $\mathrm{Mn}^{2+}(2 \mathrm{mM})$ for $2 \mathrm{~min}$. Cells were excited at $360 \mathrm{~nm}$ and fluorescence emission was monitored at $510 \mathrm{~nm}$. After $\mathrm{Mn}^{2+}$ perfusion, the decrease of Fura-2 fluorescence followed a linear decay, and the slope is correlated with the rate of the $\mathrm{Mn}^{2+}$ influx. The calculated slope is obtained by subtracting the slope of basal decreasing Fura-2 fluorescence obtained in basal conditions and after $\mathrm{Mn}^{2+}$ application. Similar experiments were made using $\mathrm{Cd}^{2+}(2 \mathrm{mM})$ instead of $\mathrm{Mn}^{2+}$ to quench Fura-2 fluorescence. Contrarily to $\mathrm{Mn}^{2+}, \mathrm{Cd}^{2+}$ entry increases Fura-2 fluorescence. Moreover, MCF10A and hTERT-HPNE were incubated with Fura-2 (as previously indicated) to measure the $\mathrm{Ca}^{2+}$ basal fluorescence ratio. During the perfusion with the extracellular solution (containing $2 \mathrm{mM}$ of $\mathrm{Ca}^{2+}$ ), cells were excited alternatively at $350 \mathrm{~nm}$ and $380 \mathrm{~nm}$. The ratio of Fura-2 fluorescence intensities measured with excitation at 350 and $380 \mathrm{~nm}\left(\mathrm{~F}_{350} / \mathrm{F}_{380}\right)$ was used as a $\left[\mathrm{Ca}^{2+}\right]_{\mathrm{i}}$ related signal. To evaluate $\mathrm{Mg}^{2+}$ basal ratio, cells were perfused with an extracellular solution containing $1 \mathrm{mM} \mathrm{Mg}^{2+}$, and Mag-Fura-2 was used as a fluoroprobe. Mag-Fura-2 fluorescence intensities (measured following excitation at 330 and $370 \mathrm{~nm}, \mathrm{~F}_{330} / \mathrm{F}_{370}$ ) were used as a $\left[\mathrm{Mg}^{2+}\right]_{\mathrm{i}}$ related signal.

\section{Cell morphology assessment}

After the $\mathrm{Cd}^{2+}$ exposure period, cells were photographed under an inverted microscope (Zeiss) at intermediate confluence. Cells clustering at $\times 200$ magnification was evaluated. Circularity index of cells at $\times 400$ magnification was calculated by Image J software (https://imagej.nih.gov/ij/).

\section{Wound healing assay}

The effect of $\mathrm{Cd}^{2+}$ exposure on cellular motility was assessed using the wound healing assay. $3 \times 10^{5}$ cells were cultured in a $35-\mathrm{mm}$ diameter dishes. When the cells have formed a confluent cell monolayer, a linear empty space was generated using sterile plastic pipette tip. The wound closure was estimated by measuring its area for each time (T0, T12h, T16h, T20h, T24h) using the Image J software (https://image j.nih.gov/ij/). 


\section{Cell migration and invasion assays}

For invasion tests, cell culture inserts (BD Falcon Cell Culture Inserts, BD Biosciences) were coated with Matrigel (Sigma-Aldrich, Inc.). The upper compartment was seeded with $2 \times 10^{4}$ cells and $4 \times 10^{4}$ of 24-h transfected hTERTHPNE and MCF10A cells, respectively, in growth medium supplemented with FCS. The lower compartments were also filled with growth medium supplemented with FCS. Thus, migration and invasion assays were performed without addition of chemoattractant. After $24 \mathrm{~h}$ of incubation at $37{ }^{\circ} \mathrm{C}$, inserts were washed by phosphate-buffered saline, fixed 10 min by methanol and stained 5 min with hematoxylin. The remaining cells on upper side were removed from the membrane by scrubbing. Cells in 20 contiguous areas at $\times 400$ magnification for each insert were counted under an inverted microscope (Zeiss). For each experiment, the number of migrant or invasive cells per area for each condition was normalized by the mean of non-exposed siControl migrant or invasive cells.

\section{Cell proliferation assays}

Cell proliferation was tested by MTT assay. Cells were seeded in 6-well plates in the same density as migration and invasion assays to prove that the variations observed are not due to a seeding difference. Then, the yellow tetrazolium salts of 3-(4,5-dimethyl-2-thiazolyl)-2,5-diphenyl-2H-tetrazolium bromide (MTT, Sigma-Aldrich, Inc.) solubilized in culture medium without FCS $(0.5 \mathrm{mg} / \mathrm{mL})$ was added to each well and incubated $50 \mathrm{~min}$ at $+37^{\circ} \mathrm{C}$ in the dark. To dissolve purple formazan crystals, the culture medium was replaced with dimethyl sulfoxide (DMSO, Sigma-Aldrich, Inc.). Absorbance of each well was quantified at $550 \mathrm{~nm}$ using an Infinite ${ }^{\circledR} 200$ Pro reader (Tecan Trading AG).

\section{Statistical analysis}

Data are presented as Mean \pm S.E.M. and the number of experiments or the number of studied cells is represented by $n$. Experiments were repeated at least in three different cell passages. Data analysis and figure conception were made using Microcal ${ }^{\mathrm{TM}}$ Origin ${ }^{\circledR}$ (Microcal Software, Inc., USA) and Clampfit (Molecular Devices, Inc., USA) software. Statistical analyses were made using Student's $t$ tests or Mann-Whitney rank sum test depending on sample normality determined by paired Wilcoxon signed-rank test using Sigma-Stat 3.0 (Systat Software, Inc.). To compare the combinate effects of $\mathrm{Cd}^{2+}$ exposure and TRPM7 silencing, a two-way analysis of variance was used followed by HolmSidak method using SigmaStat 3.0 (Systat Software, Inc.).

\section{Results}

\section{Effect of chronic cadmium exposure on TRPM7 channel expression in non-cancer epithelial cells}

Western Blot analyses were performed to evaluate how TRPM7 expression was altered in MCF10A cells exposed to cadmium $\left(\mathrm{Cd}^{2+}\right)$ when compared to the control cells. Results (displayed in Fig. 1a) show that TRPM7 relative expression increased by almost twofold in $\mathrm{Cd}^{2+}$ cells $(n=5)$ compared to control cells $(n=6 ; P<0.005)$. Furthermore, TRPM7 knockdown $(n=6)$ decreased TRPM7 relative expression by almost $75 \%$ compared to siControl $(n=6 ; P<0.05)$ in control cells, and by almost $80 \%$ in $\mathrm{Cd}^{2+}$ cells $(n=6)$ compared to siControl $(n=5 ; P<0.001)$. These data show that $\mathrm{Cd}^{2+}$ exposure increased TRPM7 expression in MCF10A cells by twofold. As TRPM7 is also overexpressed in human pancreatic ductal adenocarcinoma (PDAC) (Rybarczyk et al. 2012; Yee et al. 2015), we further assess its expression in the non-cancer pancreatic epithelial cell line, hTERT-HPNE. We confirmed that $\mathrm{Cd}^{2+}$ exposure increased TRPM7 expression in hTERT-HPNE in a similar manner than for MCF10A (Fig. 1b).

To evaluate if TRPM7 overexpression increased TRPM7 currents at the plasma membrane, MIC currents were recorded. An increase of the outward membrane current densities (recorded at $+100 \mathrm{mV}$ ) was observed during the dialysis of the intracellular media by EGTA (Fig. 1c, d). MIC current was calculated as the difference between recorded current after intracellular dialysis and the stable current recorded immediately after the patch rupture. The current-voltage (I-V) relationships of MIC currents were built (Fig. 1e, f). The I-V relationship has some of the typical features of MIC currents: inward current at negative membrane potentials, reversal potential close to $0 \mathrm{mV}$ and strong outward rectification for positive membrane potentials (Prakriya and Lewis 2002). As shown in Fig. 1e, MIC currents recorded in $\mathrm{Cd}^{2+}$ cells $(n=15)$ were significantly larger than those recorded in control cells $(n=15 ; P<0.001)$. When TRPM7 expression was downregulated, MIC currents were largely reduced in $\mathrm{Cd}^{2+}$ cells $(n=8)$ when compared to control cells $(n=8 ; P<0.001 ;$ Fig. 1 ) $)$ This result shows that the enhanced MIC current recorded in cells exposed to $\mathrm{Cd}^{2+}$ was mainly due to TRPM7 membrane channel activity.

Taken together, these data indicate that $\mathrm{Cd}^{2+}$ exposure increased TRPM7 expression and function leading to enhanced membrane MIC currents.

\section{Effect of cadmium exposure on constitutive cation influxes, and $\mathrm{Ca}^{2+}$ and $\mathrm{Mg}^{2+}$ homeostasis}

TRPM7 is a non-selective cation channel that mainly conducts $\mathrm{Ca}^{2+}$ and $\mathrm{Mg}^{2+}$. Moreover, TRPM7 is permeant 
Fig. 1 TRPM7 expression and electrophysiological activity in human epithelial cells chronically exposed to cadmium. a, b Upper panels. Lysates from MCF10A (a) and hTERTHPNE (b) exposed or not to cadmium $\left(\mathrm{Cd}^{2+}\right)$ and transfected with a scrambled siRNA (siControl) or targeting TRPM7 (siTRPM7) were immunoblotted with the anti-TRPM7 and the anti-tubulin antibodies. a, b Lower panels. Quantification of immunoblotting normalized to control cells transfected by a scrambled siRNA in MCF10A (a) and in hTERT-HPNE (b). c-f Recordings of Magnesium Inhibited Cation (MIC) currents in MCF10A cells. c MIC currents were recorded by dialyzing the intracellular media with an intrapipette solution containing cesium (Cs) and EGTA. d Time-course of outward current densities (recorded at $+100 \mathrm{mV})$ in control $(n=15$; black dots) and $\mathrm{Cd}^{2+}$ exposed cells ( $n=15$; red dots) during the dialyze of the intracellular media and the removal of intracellular $\mathrm{Mg}^{2+}$. e Currentvoltage relationships of MIC currents built as steady state for control $(n=15$; black trace) and $\mathrm{Cd}^{2+}$ exposed cells $(n=15$; red trace). f Current-voltage relationships of MIC currents recorded in MCF10A transfected with a siControl $(n=8$; red trace) or with a siTRPM7 ( $n=8$; violet trace). All results are shown as means \pm SEM (effect of $\mathrm{Cd}^{2+}$ exposure:

${ }^{\S} P<0.05$; effect of siTRPM7:

$* P<0.05, * * * P<0.001$ ) (color figure online) $\mathbf{a}$
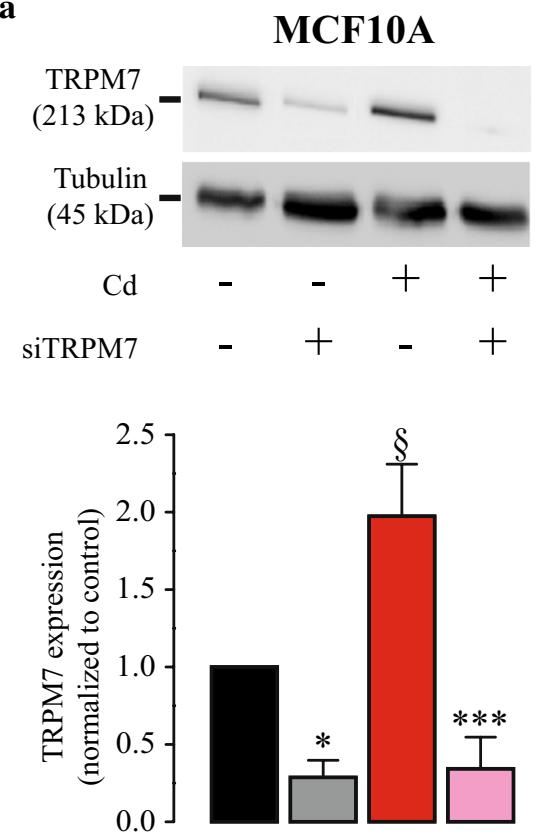

c

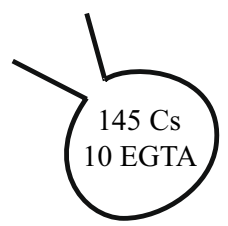

e

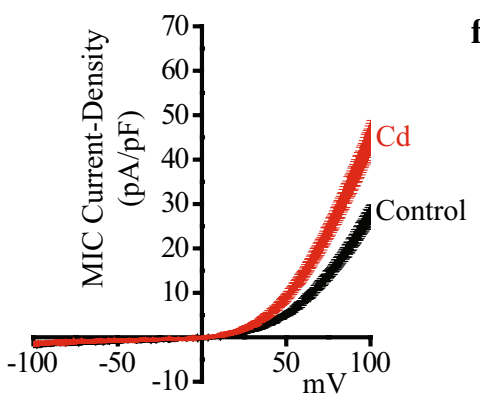

f b

\section{hTERT-HPNE}
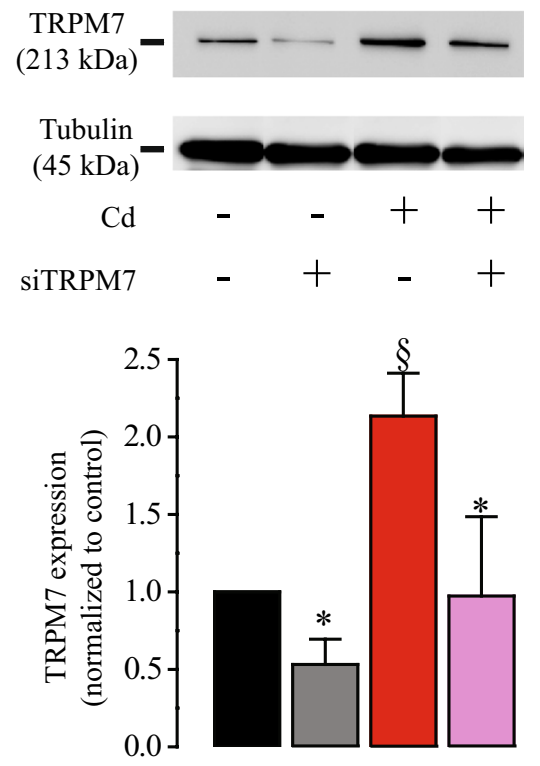

d
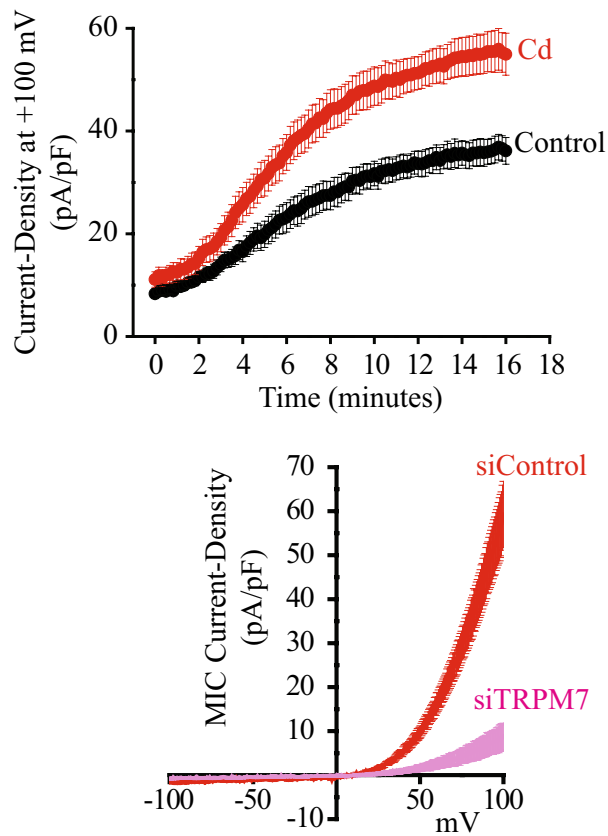

to other metals including $\mathrm{Mn}^{2+}$ (Monteilh-Zoller et al. 2003). Using the $\mathrm{Mn}^{2+}$-quenching technique, we show that chronic $\mathrm{Cd}^{2+}$ exposure increased the constitutive cation entry in MCF10A cells $(n=164)$ when compared to control cells $(n=139 ; P<0.001 ;$ Fig. $2 \mathrm{a}, \mathrm{b})$. TRPM7 silencing had no effect on control cells $(n=131)$ whereas it strongly decreased the constitutive cation entry in $\mathrm{Cd}^{2+}$ cells $(n=94 ; P<0.001)$, indicating that TRPM7 channels are mainly responsible for enhanced constitutive cation entry in MCF10A cells chronically exposed to $\mathrm{Cd}^{2+}$. Next, we studied how $\mathrm{Cd}^{2+}$ exposure alters
$\mathrm{Ca}^{2+}-$ and $\mathrm{Mg}^{2+}$ intracellular homeostasis. As shown in the Fig. 2c, the cytosolic basal $\mathrm{Ca}^{2+}$ level was larger in MCF10A exposed to $\mathrm{Cd}^{2+}(n=73)$ when compared to the control ones $(n=119 ; P=0.024)$. Surprisingly, TRPM7 silencing increased $\mathrm{Ca}^{2+}$ level in control cells $(n=85 ; P=0.018)$ whereas it was decreased in $\mathrm{Cd}^{2+}$ ones $(n=71 ; P<0.001)$. The homeostasis of $\mathrm{Mg}^{2+}$ was also studied using the $\mathrm{Mg}^{2+}$-sensitive Mag-Fura-2 fluorescent probe (Fig. 2d). Chronic $\mathrm{Cd}^{2+}$ exposure increased $\mathrm{Mg}^{2+}$ level $(n=72)$ when compared to control cells $(n=101$; $P<0.001)$. TRPM7 silencing had no effect on control 
$\mathbf{a}$

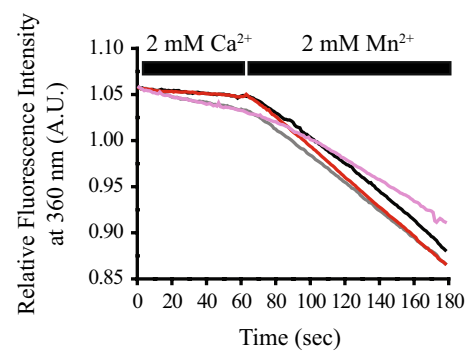

c

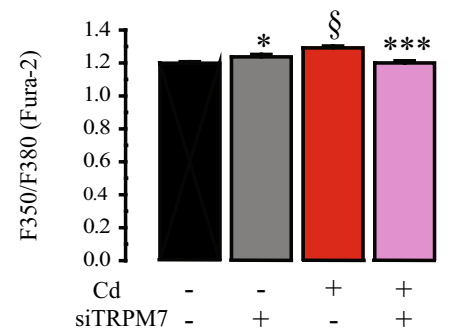

e

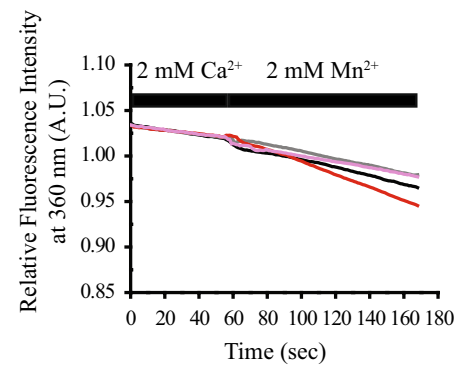

g

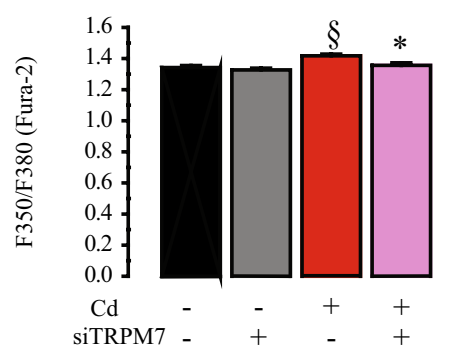

i

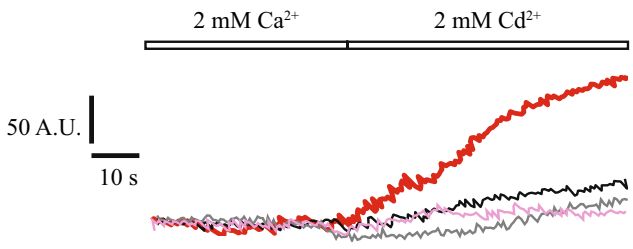

b $\begin{array}{ccccc}\mathrm{Cd} & - & - & + & + \\ \text { SiTRPM7 } & - & + & - & +\end{array}$

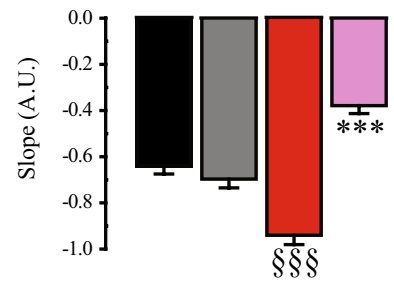

d

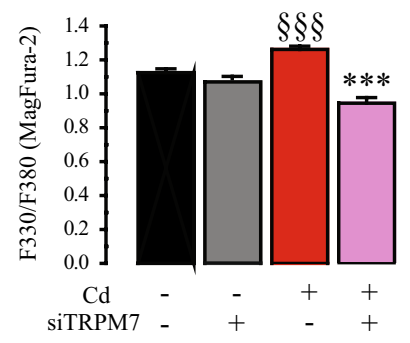

f

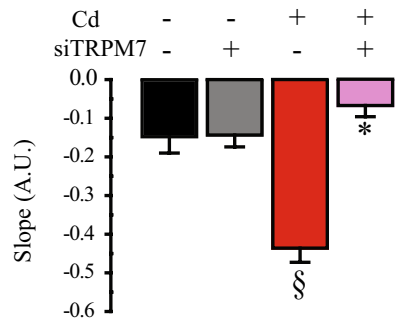

h

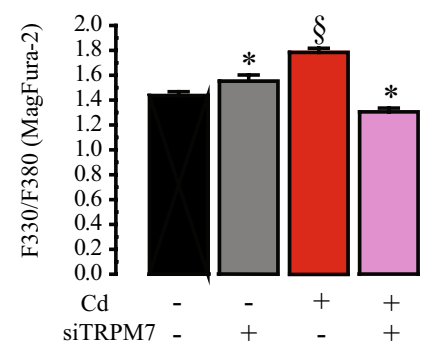

$\mathbf{j}$

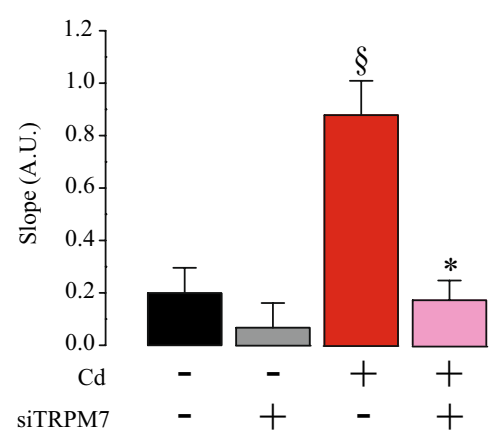

cells $(n=77)$ whereas it strongly decreased $\mathrm{Mg}^{2+}$ homeostasis in $\mathrm{Cd}^{2+}$ exposed cells $(n=55 ; P<0.001)$. Similar experiments were conducted in hTERT-HPNE cells. Contrarily to what we observed for MCF10A cells, the basal $\mathrm{Mn}^{2+}$-quenching slope was weak in hTERT-HPNE suggesting that there was hardly any constitutive cation entry in non-cancer pancreatic epithelial cells (Fig. 2e). As shown for MCF10A cells, $\mathrm{Cd}^{2+}$ exposure increased the constitutive cation entry $(n=111)$ when compared to control cells ( $n=70 ; P=0.004$; Fig. 2 e, f). TRPM7 silencing had no effect on control cells $(n=79)$ whereas it almost fully abolished the constitutive cation entry in 
4Fig. 2 Role of TRPM7 in constitutive divalent cation entry and in cytosolic calcium and magnesium levels of human epithelial cells chronically exposed to cadmium. a Constitutive divalent cation entry estimated by manganese $\left(\mathrm{Mn}^{2+}\right)$ quenching of fura-2 fluorescent probe in MCF10A cells. $\mathrm{Mn}^{2+}$-quenching was measured (at $360 \mathrm{~nm}$ ) in control cells ( $n=139$; black trace), in control cells transfected with a siRNA targeting TRPM7 (siTRPM7; $n=131$; grey trace), in cadmium exposed $\left(\mathrm{Cd}^{2+}\right)$ cells transfected with a siControl $(n=164$; red trace), and in $\mathrm{Cd}^{2+}$ cells transfected with a siTRPM7 ( $n=94$; violet trace). b Quantification of $\mathrm{Mn}^{2+}$-quench slope in MCF10A cells. c Estimation of cytosolic $\mathrm{Ca}^{2+}$ levels by measurement of fura- 2 basal fluorescence in MCF10A cells. Fura-2 fluorescence ratio (F350/380) were measured in control cells $(n=119)$, in control cells transfected with a siTRPM7 $(n=85)$, in $\mathrm{Cd}^{2+}$ cells $(n=73)$, and in $\mathrm{Cd}^{2+}$ cells transfected with a siTRPM7 $(n=71)$. d Estimation of cytosolic $\mathrm{Mg}^{2+}$ levels by measurement of MagFura-2 basal fluorescence in MCF10A cells. MagFura-2 fluorescence ratio (F330/380) were measured in control cells $(n=101)$, in control cells transfected with a siTRPM7 $(n=77)$, in $\mathrm{Cd}^{2+}$ cells $(n=72)$, and in $\mathrm{Cd}^{2+}$ cells transfected with a siTRPM7 $(n=55)$. e Constitutive divalent cation entry estimated by $\mathrm{Mn}^{2+}$-quenching of fura-2 fluorescent probe in hTERT-HPNE cells. $\mathrm{Mn}^{2+}$-quenching was measured (at $360 \mathrm{~nm}$ ) in control cells $(n=70$; black trace), in control cells transfected with a siTRPM7 $(n=79$; grey trace), in $\mathrm{Cd}^{2+}$ cells transfected with a siControl $(n=111$; red trace), and in $\mathrm{Cd}^{2+}$ cells transfected with a siTRPM7 ( $n=67$; violet trace). $\mathbf{f}$ Quantification of $\mathrm{Mn}^{2+}$-quench slope in hTERT-HPNE cells. g Estimation of cytosolic $\mathrm{Ca}^{2+}$ levels by measurement of fura- 2 basal fluorescence in hTERT-HPNE cells. Fura-2 fluorescence ratio $(\mathrm{F} 350 / 380)$ were measured in control cells $(n=79)$, in control cells transfected with a siTRPM7 $(n=57)$, in $\mathrm{Cd}^{2+}$ cells $(n=87)$, and in $\mathrm{Cd}^{2+}$ cells transfected with a siTRPM7 $(n=47)$. h Estimation of cytosolic $\mathrm{Mg}^{2+}$ levels by measurement of MagFura-2 basal fluorescence in hTERT-HPNE cells. MagFura-2 fluorescence ratio (F330/380) were measured in control cells $(n=93)$, in control cells transfected with a siTRPM7 $(n=54)$, in $\mathrm{Cd}^{2+}$ cells $(n=103)$, and in $\mathrm{Cd}^{2+}$ cells transfected with a siTRPM7 $(n=63)$. i $\mathrm{Cd}^{2+}$ entry estimated by $\mathrm{Cd}^{2+}$-induced positive quenching of fura-2 fluorescent probe in MCF10A cells. $\mathrm{Cd}^{2+}$-quenching was measured (at $360 \mathrm{~nm}$ ) in control cells ( $n=14$; black trace), in control cells transfected with a siTRPM7 $\left(n=14\right.$; grey trace), in $\mathrm{Cd}^{2+}$ cells transfected with a siControl $(n=23$; red trace), and in $\mathrm{Cd}^{2+}$ cells transfected with a siTRPM7 ( $n=23$; violet trace). j Quantification of $\mathrm{Cd}^{2+}$-quench slope in MCF10A cells. All results are shown as means \pm SEM (effect of $\mathrm{Cd}^{2+}$ exposure: ${ }^{\S} P<0.05,{ }^{\S \S} P<0.001$; effect of siTRPM7: $* P<0.05$, $\left.* * * P<0.001\right)$ (color figure online)

$\mathrm{Cd}^{2+}$ exposed cells $\left(n=67 ; P<0.05\right.$. Chronic $\mathrm{Cd}^{2+}$ exposure further increased $\mathrm{Ca}^{2+}$ homeostasis in hTERT-HPNE cells $(n=87)$ when compared to the control ones $(n=79$; $P<0.05$; Fig. 2g). TRPM7 silencing had no effect on control cells $(n=57)$ whereas it decreased $\mathrm{Ca}^{2+}$ homeostasis in $\mathrm{Cd}^{2+}$ exposed cells $(n=47 ; P<0.05) . \mathrm{Mg}^{2+}$ cytosolic level was also larger in hTERT-HPNE exposed to $\mathrm{Cd}^{2+}$ $(n=103)$ than in control cells $(n=93 ; P<0.05$, Fig. $2 h)$. In control cells, TRPM7 silencing induced a slight increase of cytosolic $\mathrm{Mg}^{2+}(n=54 ; P<0.05)$, whereas it induced a strong decrease in $\mathrm{Cd}^{2+}$ exposed cells $(n=63 ; P<0.05)$.

TRPM7 is also involved in $\mathrm{Cd}^{2+}$ entry (Martineau et al. 2010; Monteilh-Zoller et al. 2003). Here, we used the $\mathrm{Cd}^{2+}$ quenching of Fura-2 fluorescence technique to assess the entry of $\mathrm{Cd}^{2+}$ in MCF10A cells (Fig. $2 \mathrm{i}, \mathrm{j}$ ). We show that
MCF10A cells were permeant to $\mathrm{Cd}^{2+}$ because perfusion with $2 \mathrm{mM} \mathrm{Cd}^{2+}$ induced a positive quench of Fura-2 ( $n=14$; Fig. 2 i, black trace). The quenching slope was larger in $\mathrm{Cd}^{2+}$ exposed cells indicating that these latter were more permeant to external $\mathrm{Cd}^{2+}(n=23 ; P<0.05$. TRPM7 silencing had no effect in control cells $(n=14)$ while it decreased $\mathrm{Cd}^{2+}$ entry in $\mathrm{Cd}^{2+}$ exposed cells $(n=23 ; P<0.05)$. These results suggest that TRPM7 channels provide a favorite route for $\mathrm{Cd}^{2+}$ entry in cells chronically exposed to $\mathrm{Cd}^{2+}$. However, TRPM7 silencing had no effect on $\mathrm{Cd}^{2+}$ entry in control cells suggesting that $\mathrm{Cd}^{2+}$ enters through other transporters.

To summarize, chronic $\mathrm{Cd}^{2+}$ exposure induced an increase of the divalent cation constitutive entry in both MCF10A and hTERT-HPNE cells as well as higher cytosolic levels, particularly for $\mathrm{Mg}^{2+}$. These effects were abolished by TRPM7 silencing indicating that TRPM7 overexpression induced by chronic $\mathrm{Cd}^{2+}$ exposure led to enhanced divalent cation constitutive entry and $\mathrm{Mg}^{2+}$ overload.

\section{Effect of cadmium exposure on cell shape and organization}

The membrane capacitance recorded using whole-cell patch clamp can be used to estimate membrane surface. We did not observe any difference between $\mathrm{Cd}^{2+}$ exposed $(19.9 \pm 1.1$ $\mathrm{pF} ; n=36)$ and control cells $(19.5 \pm 1.0 \mathrm{pF} ; n=90 ; P>0.05)$ indicating that $\mathrm{Cd}^{2+}$ exposure did not change the lipid bilayer surface.

On the other hand, a modification of the cell organization was observed in MCF10A cells following $\mathrm{Cd}^{2+}$ exposure (Fig. 3). Indeed, control cells were organized as clusters with cell-cell junctions whereas $\mathrm{Cd}^{2+}$ exposed cells were more individualized (Fig. 3a). TRPM7 silencing restored cell clustering in $\mathrm{Cd}^{2+}$ exposed cells (Fig. 3b). However, $\mathrm{Cd}^{2+}$ exposure had no effect on hTERT-HPNE cell organization and morphology (data not shown).

Moreover, many MCF10A cells exposed to $\mathrm{Cd}^{2+}$ presented a rounded morphology (Fig. 3b, yellow arrows). Circularity index was calculated to confirm the effect of $\mathrm{Cd}^{2+}$ exposure on MCF10A morphology (Fig. 3c). $\mathrm{Cd}^{2+}$ exposed cells displayed indeed a higher circularity index $(n=192)$ than control cells $(n=197 ; P<0.05)$. While TRPM7 silencing had no effect on control cell morphology $(n=193)$, it reversed the rounded shape induced by $\mathrm{Cd}^{2+}$ exposure $(n=186 ; P<0.05)$.

Taken together, our data show that $\mathrm{Cd}^{2+}$ exposure induced a change in MCF10A cell phenotype which is mediated by TRPM7 channel expression. 
a
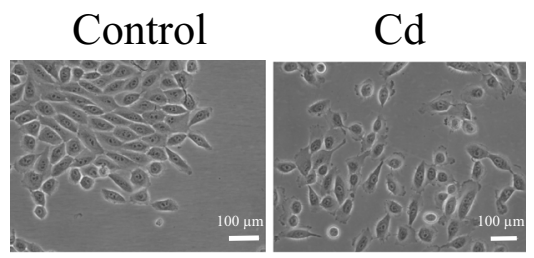

b Control
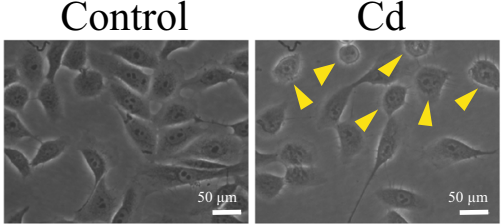

siTRPM7
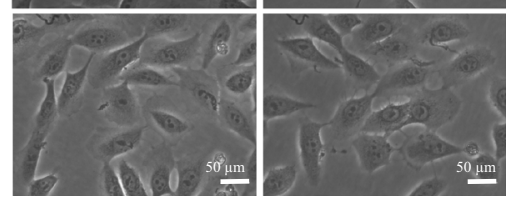

c

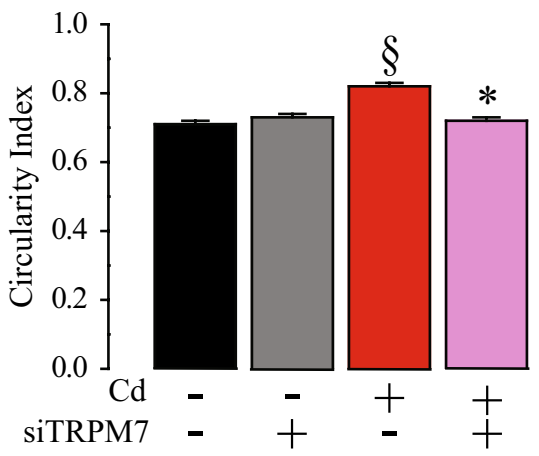

Fig. 3 Involvement of TRPM7 in MCF10A cell organization and morphology alterations induced by cadmium exposure. a Photography of control MCF10A cells and chronically exposed to cadmium $\left(\mathrm{Cd}^{2+}\right.$; scale bar $\left.=100 \mu \mathrm{m}\right)$. b Photography of control and $\mathrm{Cd}^{2+}$ MCF10A cells transfected with a scrambled siRNA (siC) or with a siRNA targeting TRPM7 (siTRPM7). Yellow arrows show cells with rounded phenotype in $\mathrm{Cd}^{2+}$ cells (scale bar $=50 \mu \mathrm{m}$ ). c Quantification of circularity index in control siC cells $(n=197)$, in control siTRPM7 cells $(n=193)$, in $\mathrm{Cd}^{2+}$ siC cells $(n=192)$, and in $\mathrm{Cd}^{2+}$ siTRPM7 cells $(n=186)$. All results are shown as means \pm SEM (effect of $\mathrm{Cd}^{2+}$ exposure: ${ }^{\S} P<0.05$; effect of siTRPM7: $* P<0.05$ ) (color figure online)

\section{Expression of EMT markers in MCF10A cells exposed to cadmium}

The first step of the metastatic cascade is the epithelial-tomesenchymal transition (EMT), that is characterized by morphological changes (including loss of cell-cell junctions). Here, we assessed the expression of some EMT markers in MCF10A cells following $\mathrm{Cd}^{2+}$ exposure (Fig. 4). Chronic $\mathrm{Cd}^{2+}$ exposure induced a shift of cadherin expression profile with a decrease of E-Cadherin and an increase of N-Cadherin (Fig. 4a). E/N-Cadherin switch was evaluated by E/N Cadherin expression ratio (Fig. 4b). Chronic $\mathrm{Cd}^{2+}$ exposure a N-Cadherin

$(125 \mathrm{kDa})$

$\underset{(110 \mathrm{kDa})}{\mathrm{E}-C a d h e r i n}-\longrightarrow$
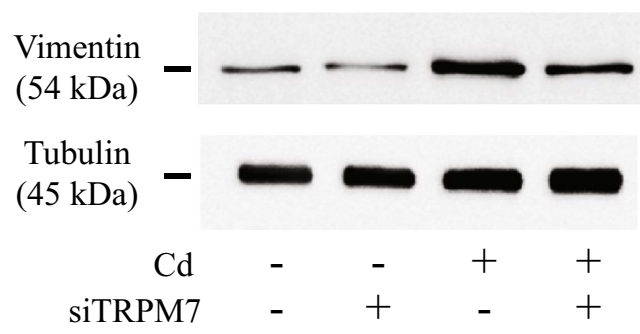

b

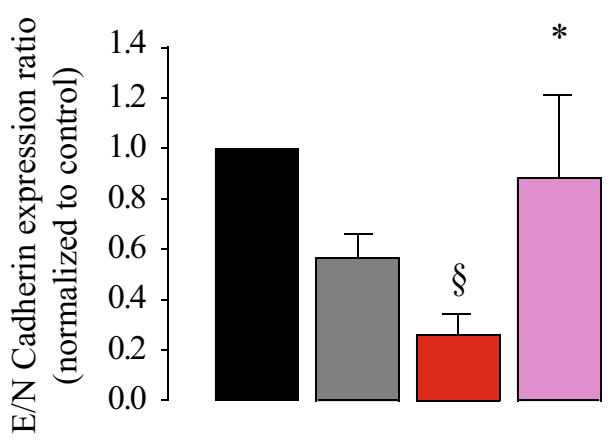

c

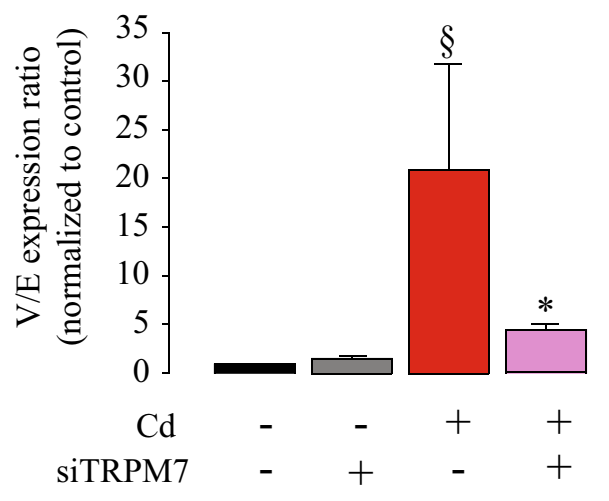

Fig. 4 TRPM7 regulates epithelial-to-mesenchymal transition induced by cadmium exposure in MCF10A cells. a Lysates from MCF10A (exposed or not to cadmium $\left(\mathrm{Cd}^{2+}\right)$ and transfected with a scrambled siRNA (siControl) or targeting TRPM7 (siTRPM7) were immunoblotted with the anti-N-Cadherin, the anti-E-Cadherin, the anti-vimentin and the anti-tubulin antibodies. b E- to N-Cadherin switch quantified by E/N Cadherin expression ratio in control cells $(n=7)$, in control cells transfected with a siTRPM7 $(n=7)$, in $\mathrm{Cd}^{2+}$ cells $(n=7)$, and in $\mathrm{Cd}^{2+}$ cells transfected with a siTRPM7 $(n=7)$. c Quantification of Vimentin/E-Cadherin (V/E) expression ratio in control cells $(n=7)$, in control cells transfected with a siTRPM7 $(n=7)$, in $\mathrm{Cd}^{2+}$ cells $(n=7)$, and in $\mathrm{Cd}^{2+}$ cells transfected with a siTRPM7 $(n=7)$. All results are shown as means \pm SEM (effect of $\mathrm{Cd}^{2+}$ exposure: ${ }^{\S} P<0.05$; effect of siTRPM7: $* P<0.05$ ) 
decreased E/N Cadherin ratio $(n=7 ; P<0.05)$. TRPM7 silencing had no effect in control cells $(n=7 ; P=0.099)$ but restored E/N-Cadherin ratio in $\mathrm{Cd}^{2+}$ exposed cells $(n=7$; $P<0.05)$. Vimentin/E-cadherin ratio (V/E ratio) was also studied as a mesenchymal marker (Murai et al. 2014). V/E ratio was increased in $\mathrm{Cd}^{2+}$ exposed cells $(n=7 ; P<0.05)$. Again, TRPM7 silencing partially restored V/E ratio in $\mathrm{Cd}^{2+}$ exposed cells $(n=7 ; P<0.05)$, but had no effect in control cells (Fig. 4c).

Our results show that $\mathrm{Cd}^{2+}$ exposure induced EMT in MCF10A cells. Interestingly, TRPM7 channel inhibition prevented the changes of EMT marker expression induced by chronic $\mathrm{Cd}^{2+}$ exposure.

\section{Role of TRPM7 in cell migration and invasion induced by chronic cadmium exposure}

Previous studies have shown that $\mathrm{Cd}^{2+}$ exposure transforms MCF10A cell into a basal-like phenotype, that is characterized by enhanced cell migration and invasiveness (Benbrahim-Tallaa et al. 2009). Here, we confirmed that $\mathrm{Cd}^{2+}$ exposure confers abilities to MCF10A for migration (Fig. $5 \mathrm{a}-\mathrm{c}$ ), since cells chronically exposed to $\mathrm{Cd}^{2+}$ were able to close a scratch wound faster than the control cells $(n=8, P<0.01)$. TRPM7 silencing reduced the cell motility in $\mathrm{Cd}^{2+}$ exposed MCF10A $(n=8, P<0.01)$ but not in control cells (Fig. 5a, b). We further tested the migration properties using Boyden chamber assays. We confirmed that $\mathrm{Cd}^{2+}$ exposure was able to stimulate MCF10A cell migration $(n=160 ; P<0.001)$. TRPM7 silencing inhibited cell migration in control cells $(n=160 ; P<0.001)$ and this effect was even more pronounced in $\mathrm{Cd}^{2+}$ exposed cells $(n=160$; $P<0.001$; Fig. 5c). Furthermore, we were able to confirm that $\mathrm{Cd}^{2+}$ exposure enhanced MCF10A cell invasion $(n=120 ; P<0.001 ;$ Fig. $5 \mathrm{~d})$. As for cell migration, TRPM7 silencing inhibited cell invasion in control cells and even more in $\mathrm{Cd}^{2+}$ exposed cells $(n=120 ; P<0.001)$. As $\mathrm{Cd}^{2+}$ exposure is also able to transform epithelial pancreatic cells into a more aggressive phenotype, cell invasion was tested in hTERT-HPNE cells (Fig. 5e). $\mathrm{Cd}^{2+}$ exposure also enhanced cell invasion in hTERT-HPNE $(n=60 ; P<0.001)$, whereas TRPM7 silencing inhibited the cell invasion in $\mathrm{Cd}^{2+}$ exposed cells only $(n=60 ; P<0.001)$.

\section{TRPM7 overexpression in MCF10A}

To prove the promigratory role of TRPM7 in non-cancer epithelial cells, zebrafish (ZF) TRPM7 was overexpressed in MCF10A cells. We observed that TRPM7 overexpression increased cell migration from $1 \pm 0.05$ to $1.49 \pm 0.06$ compared to control $(n=120 ; P<0.001$, Mann-Whitney Rank
Sum Test; Fig. 6a). TRPM7 overexpression had no effect on cell viability assessed by MTT assay $(n=15 ; P>0.05$; Fig. 6b).

Taken together, our results clearly show that TRPM7 is involved in enhanced cell motility and invasion induced by $\mathrm{Cd}^{2+}$ exposure, in human epithelial cells.

\section{Discussion}

Cadmium $\left(\mathrm{Cd}^{2+}\right)$ is a xenobiotic which is known to induce alteration of gene expression (Chen et al. 2019; Rani et al. 2014). $\mathrm{Cd}^{2+}$ enters into the cells through numerous transporters including TRPM7 (Thevenod et al. 2019). TRPM7 is for instance involved in $\mathrm{Cd}^{2+}$ entry in HEK293 expressing TRPM7 (Monteilh-Zoller et al. 2003) and in human osteoclasts (Martineau et al. 2010). Using $\mathrm{Cd}^{2+}$-quenching of Fura-2, we show that TRPM7 is probably not involved in basal $\mathrm{Cd}^{2+}$ entry in MCF10A cells. This suggests that other transporters are required for cell $\mathrm{Cd}^{2+}$ uptake in human mammary non-cancer cells. In the present study, we show that: (1) $\mathrm{Cd}^{2+}$ exposure increases TRPM7 expression; (2) TRPM7 overexpression is followed by an increase of membrane MIC currents and constitutive divalent cation entry with increased cytosolic $\mathrm{Mg}^{2+}$ levels; (3) $\mathrm{Cd}^{2+}$ exposure induces EMT through TRPM7 expression; (4) migration and invasion are enhanced in $\mathrm{Cd}^{2+}$ exposed cells.

Previous studies have shown that $\mathrm{Cd}^{2+}$ exposure leads to non-cancer epithelial cell transformation into an invasive phenotype, by an unknown mechanism that does not involve estrogen receptor activation (Benbrahim-Tallaa et al. 2009; Qu et al. 2012). Here, we show for the first time that TRPM7 channels participate in this neoplastic transformation. TRPM7 is a non-selective cation channel which is overexpressed in numerous cancers, including breast cancer and pancreatic ductal adenocarcinoma (Dhennin-Duthille et al. 2011; Gautier et al. 2016; Middelbeek et al. 2012; Rybarczyk et al. 2012; Yee et al. 2015). We show that $\mathrm{Cd}^{2+}$ exposure induces TRPM7 overexpression in both human mammary and pancreatic non-cancer epithelial cells, suggesting that TRPM7 could be used as a biomarker for cell transformation. Interestingly, TRPM6 was downregulated following $\mathrm{Cd}^{2+}$ exposure (supplemental data) indicating that TRPM7 is probably the main $\mathrm{Ca}^{2+}$ / $\mathrm{Mg}^{2+}$ channel overexpressed in cells exposed to $\mathrm{Cd}^{2+}$. Moreover, this result also confirms that TRPM7 but not TRPM6 is required for the acquisition of an invasive phenotype. To our knowledge, our study provided a unique cellular model of TRPM7 overexpression induced by pollutant exposure.

TRPM7 overexpression induces an increase of both TRPM7 membrane currents and cation constitutive entry, indicating that overexpressed TRPM7 channels are 
Fig. 5 TRPM7 silencing inhibits human epithelial cell migration and invasion stimulated by chronic cadmium exposure. a Photography of wound-healing assays taken immediately after the scratch (T0) or $24 \mathrm{~h}$ later (T24) in MCF10A cells. b Quantification of woundhealing closure in control cells transfected with a scrambled siRNA (siC) $(n=8$; black dots), in control cells transfected with a siRNA targeting TRPM7 (siTRPM7; $n=8$; grey dots), in cadmium exposed $\left(\mathrm{Cd}^{2+}\right)$ cells transfected with a siC $(n=8$; red dots), and in $\mathrm{Cd}^{2+}$ cells transfected with a siTRPM7 $(n=9$; violet dots). Scratch opening measurements were normalized to the control siC condition. c MCF10A cell migration assessment after $24 \mathrm{~h}$ in Boyden chambers. Cell migration was normalized to the control siC condition. d MCF10A cell invasion assessment after $24 \mathrm{~h}$ in Boyden chambers containing Matrigel. Cell invasion was normalized to the control siC condition. e hTERT-HPNE cell invasion assessment after $24 \mathrm{~h}$ in Boyden chambers containing Matrigel. Cell invasion was normalized to the control siC condition. All results are shown as means \pm SEM (effect of $\mathrm{Cd}^{2+}$ exposure: ${ }^{\S \S} P<0.01$, $\S \S \$ P<0.001$; effect of siTRPM7: $* * * P<0.001$ ) (color figure online) $\mathbf{a}$

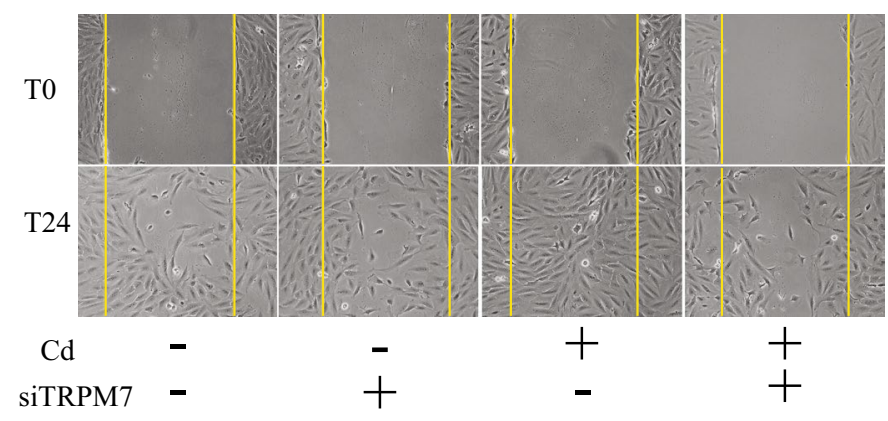

b

c

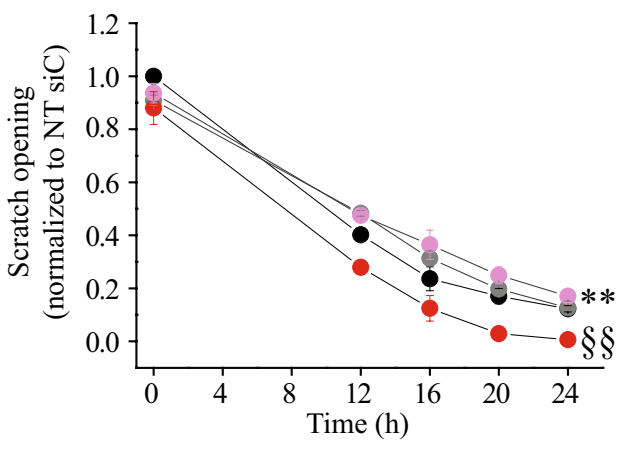

d MCF10A

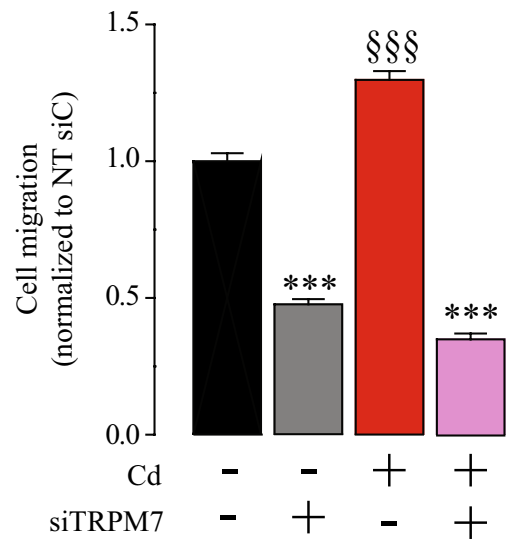

e

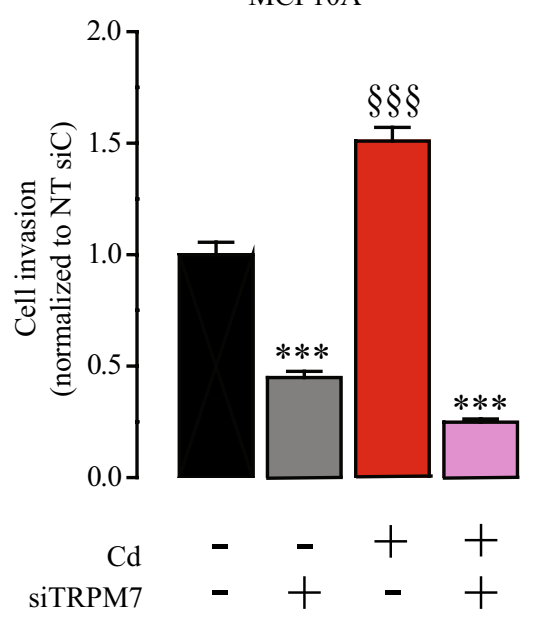

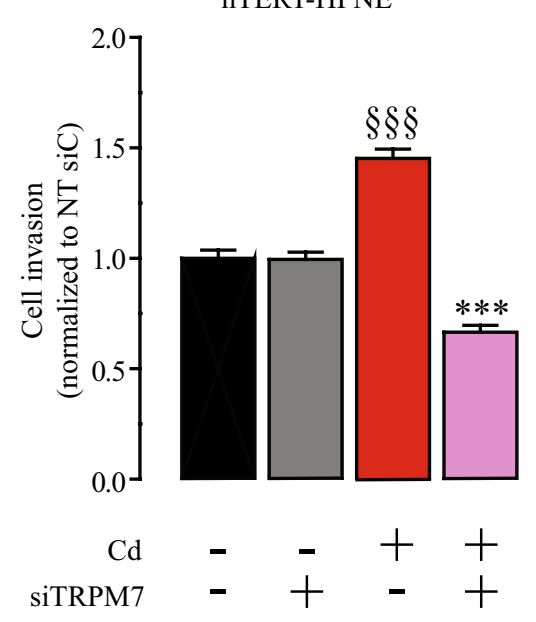

mainly located at the plasma membrane. Consequently, both cytosolic $\mathrm{Ca}^{2+}$ and $\mathrm{Mg}^{2+}$ are increased in $\mathrm{Cd}^{2+}$ exposed cells. These results are quite surprising for mammary cells because we previously showed that TRPM7 regulates $\mathrm{Ca}^{2+}$ homeostasis specifically in non-invasive MCF-7 breast cancer cells (Guilbert et al. 2009). However, TRPM7 silencing had no effect on $\mathrm{Ca}^{2+}$ and $\mathrm{Mg}^{2+}$ homeostasis in both invasive MDA-MB-231 and MDA-MB-435S cancer cells (Guilbert et al. 2013). Furthermore, it has been shown that TRPM7 regulates metastasis formation and dissemination in a model of mouse xenograft using
MDA-MB-231 by regulating myosin II-based cellular tension through its kinase domain (Middelbeek et al. 2012). While TRPM7 promotes the formation of $\mathrm{Ca}^{2+}$ sparks and invadosome in neuroblastoma cells, the role of TRPM7 on invadosome formation is independent of $\mathrm{Ca}^{2+}$ influx (Visser et al. 2013). However, the role of $\mathrm{Mg}^{2+}$ has not been assessed in these two latter studies. It may be interesting to study the regulation of TRPM7 kinase domain by $\mathrm{Mg}^{2+}$ in cancer cell migration and invasion.

Regarding the pancreatic cells, we and others previously showed that TRPM7 is overexpressed in pancreatic ductal 


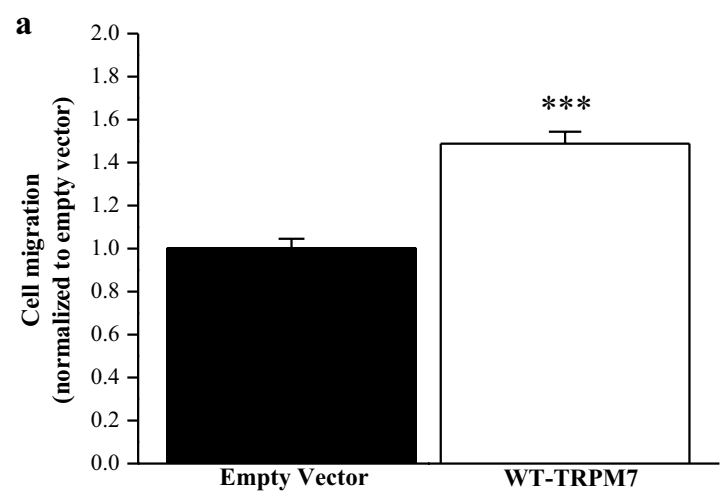

c

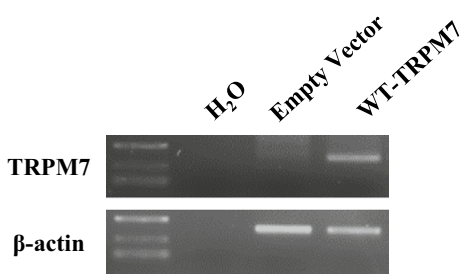

Fig. 6 Overexpression of TRPM7 in MCF10A cells. a Cell migration in MCF10A transfected with empty vector or wild-type (WT) TRPM7 $(n=120)$. b Cell viability in MCF10A transfected with

adenocarcinoma in relation with metastasis and survival (Rybarczyk et al. 2012, 2017; Yee et al. 2015). TRPM7 regulates both pancreatic cancer cell migration and invasion through $\mathrm{Mg}^{2+}$ entry (Rybarczyk et al. 2012, 2017). It has been recently shown that TRPM7 also participates to $\mathrm{Mg}^{2+}$ uptake and cell proliferation in cancer colon cells (Luongo et al. 2018). Here, we show that $\mathrm{Cd}^{2+}$ exposure was able to promote a larger increase of cytosolic $\mathrm{Mg}^{2+}$ than for $\mathrm{Ca}^{2+}$. Taken together with the recent literature, our data strongly suggest that TRPM7 overexpression leads to enhanced cytosolic $\mathrm{Mg}^{2+}$ in epithelial cells exposed to $\mathrm{Cd}^{2+}$.

MCF10A exposed to $\mathrm{Cd}^{2+}$ are not organized in clusters and have a rounded-shaped morphology, unlike control ones. These effects can be reverted by silencing TRPM7. TRPM7 knockdown can disorganize cytoskeleton in mesenchymal MDA-MB-231 which lose their spindle-shaped morphology (Middelbeek et al. 2012). TRPM7 is also known to participate in the epithelial-to-mesenchymal transition (EMT) in breast cancer (Davis et al. 2014; Kuipers et al. 2018; Sun et al. 2018). In the present study, we also demonstrate that $\mathrm{Cd}^{2+}$ exposure increases EMT markers $\mathrm{N}$-Cadherin and Vimentin, while E-Cadherin is decreased in mammary epithelial cells. TRPM7 silencing dramatically reduces EMT marker expression in mammary epithelial cells exposed to $\mathrm{Cd}^{2+}$. EMT marker expression and the acquisition of a rounded-shaped morphology strongly suggest that $\mathrm{Cd}^{2+}$ exposure induces collective-to-amoeboid transition in MCF10A. Interestingly, it has been shown that other factors

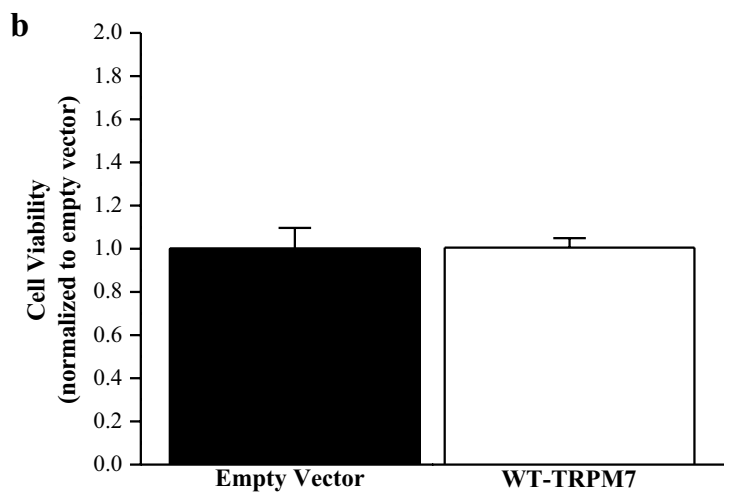

empty vector or WT-TRPM7 $(n=15)$. $\mathbf{c}$ Validation of TRPM7 overexpression by RT-PCR in MCF10A cells. All the results are shown as means \pm SEM $(* * * P<0.001$, Mann-Whitney Rank Sum Test)

like hypoxia promote EMT in epithelial cancer cells leading to collective-to-amoeboid migration (Lehmann et al. 2017). However, $\mathrm{Cd}^{2+}$ exposure had no effect on pancreatic cell morphology, nor on EMT marker expression (data not shown). It has been recently shown that pancreatic cancer cells can invade and form metastasis independently of EMT (Chen et al. 2018; Zheng et al. 2015). Moreover, E-Cadherin is required for liver metastasis suggesting that EMT is not necessary for metastasis cascade in pancreatic ductal adenocarcinoma (Reichert et al. 2018).

Enhanced cell invasion in both mammary and pancreatic epithelial cells after chronic $\mathrm{Cd}^{2+}$ exposure has already been published (Benbrahim-Tallaa et al. 2009; Qu et al. 2012). Here, we show that TRPM7 regulates invasiveness in mammary non-cancer epithelial cells. Moreover, TRPM7 silencing almost fully abolishes invasiveness in $\mathrm{Cd}^{2+}$ exposed cells, suggesting that $\mathrm{Cd}^{2+}$-induced cell invasion is mainly regulated by TRPM7 in mammary epithelial cells. In noncancer pancreatic epithelial cells, TRPM7 does not regulate cell invasion. However, TRPM7 silencing strongly reduces $\mathrm{Cd}^{2+}$-induced cell invasion as already shown for pancreatic cancer cells (Rybarczyk et al. 2017). Thus, it is tempting to speculate that TRPM7 regulated invasion specifically in cancer cell for pancreatic tissue. Taken together these results confirm that TRPM7 is a key player of invasiveness in pancreatic cancer cells. $\mathrm{Cd}^{2+}$ has been identified as a class I human carcinogen for lung cancer since 2004, but there are fewer evidence for a direct relationship between 
Fig. 7 Model for TRPM7 overexpression in transformed mammary epithelial cells by chronic cadmium exposure. Chronic exposure to cadmium induces TRPM7 overexpression at the plasma membrane of human epithelial cells leading to increased divalent cation influx, including cadmium influx. In transformed cells, TRPM7 regulates epithelial-to-mesenchymal transition as well as the acquisition of an invasive phenotype

\section{Mammary epithelial cell}

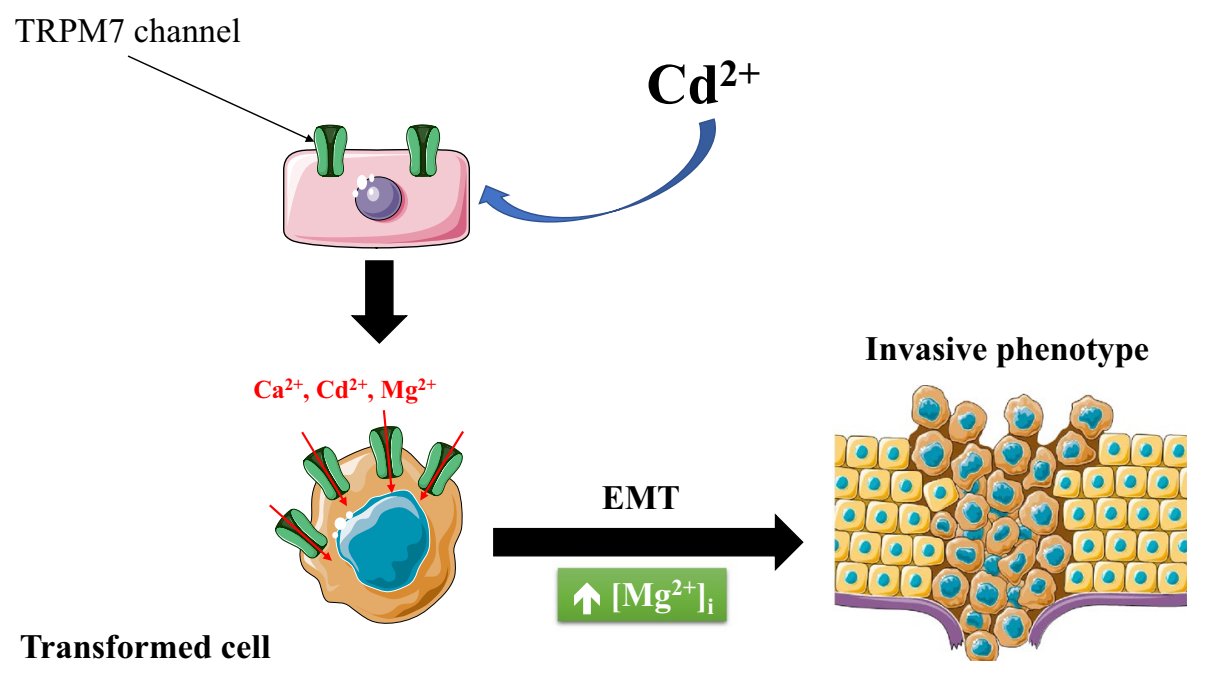

$\mathrm{Cd}^{2+}$ exposure and breast cancer/pancreatic ductal adenocarcinoma occurrence. Nevertheless, our data confirm that chronic $\mathrm{Cd}^{2+}$ exposure transforms human mammary and pancreatic epithelial cells into a more invasive phenotype. In the present study, we show that TRPM7 overexpression induced by $\mathrm{Cd}^{2+}$ exposure is linked to EMT and migration/ invasion enhancement in non-cancer epithelial cells. However, there is no evidence showing that $\mathrm{Mg}^{2+}$ and/or $\mathrm{Ca}^{2+}$ entry through TRPM7 was directly involved in the acquisition of this invasive phenotype.

In conclusion, we show that TRPM7 is overexpressed in $\mathrm{Cd}^{2+}$ exposed epithelial cells, leading to $\mathrm{Mg}^{2+}$ homeostasis unbalance and enhanced cell invasiveness (Fig. 7).

Acknowledgements AV is a recipient from the Region Hauts-deFrance. This work has been supported by FEDER, La Ligue Contre le Cancer (Comité de l'Oise et Septentrion), le Cancéropôle NordOuest (CNO) and l'Université de Picardie Jules Verne (UPJV). We thank Aurélie Dupond-Deshorgues and Marie-Sophie Telliez for their technical helps.

Author contributions AV did the experiments (cell exposure, western-blot, calcium and magnesium imaging, cell migration and invasion assays, cell morphology assays). FH did the cadmium quenching experiments. GF did the electrophysiology and the wound healing assays. HOA helped to design the study. IDD did the RT-PCR for the detection of TRPM6 and TRPM7 expression. MG designed the study, did the TRPM7 overexpression experiments and wrote the manuscript. PK helped to design the study and corrected the manuscript. PR and TL contributed to the cell exposure and to the protein extraction for western-blot. SBP and BB contributed to the cell morphology and EMT assays.

\section{Compliance with ethical standards}

Conflict of interest All authors declare they have no actual or potential competing financial interest. The authors declare no conflict of interest.
Open Access This article is licensed under a Creative Commons Attribution 4.0 International License, which permits use, sharing, adaptation, distribution and reproduction in any medium or format, as long as you give appropriate credit to the original author(s) and the source, provide a link to the Creative Commons licence, and indicate if changes were made. The images or other third party material in this article are included in the article's Creative Commons licence, unless indicated otherwise in a credit line to the material. If material is not included in the article's Creative Commons licence and your intended use is not permitted by statutory regulation or exceeds the permitted use, you will need to obtain permission directly from the copyright holder. To view a copy of this licence, visit http://creativecommons.org/licenses/by/4.0/.

\section{References}

Benbrahim-Tallaa L, Tokar EJ, Diwan BA, Dill AL, Coppin JF, Waalkes MP (2009) Cadmium malignantly transforms normal human breast epithelial cells into a basal-like phenotype. Environ Health Perspect 117:1847-1852. https://doi.org/10.1289/ehp.0900999

Chen Y et al (2018) Dual reporter genetic mouse models of pancreatic cancer identify an epithelial-to-mesenchymal transitionindependent metastasis program. EMBO Mol Med. https://doi. org/10.15252/emmm.201809085

Chen QY, DesMarais T, Costa M (2019) Metals and Mechanisms of Carcinogenesis. Annu Rev Pharmacol Toxicol 59:537-554. https ://doi.org/10.1146/annurev-pharmtox-010818-021031

Darbre PD (2006) Metalloestrogens: an emerging class of inorganic xenoestrogens with potential to add to the oestrogenic burden of the human breast. J Appl Toxicol 26:191-197. https://doi. org/10.1002/jat. 1135

Davis FM et al (2014) Induction of epithelial-mesenchymal transition (EMT) in breast cancer cells is calcium signal dependent. Oncogene 33:2307-2316. https://doi.org/10.1038/onc.2013.187

Dhennin-Duthille I et al (2011) High expression of transient receptor potential channels in human breast cancer epithelial cells and tissues: correlation with pathological parameters. Cell Physiol Biochem 28:813-822. https://doi.org/10.1159/000335795 
Fasolato C, Hoth M, Penner R (1993) Multiple mechanisms of manganese-induced quenching of fura-2 fluorescence in rat mast cells. Pflugers Archiv Eur J Physiol 423:225-231

Gautier M, Perriere M, Monet M, Vanlaeys A, Korichneva I, Dhennin-Duthille I, Ouadid-Ahidouch H (2016) Recent advances in oncogenic roles of the TRPM7 chanzyme. Curr Med Chem 23:4092-4107

Guilbert A et al (2013) Transient receptor potential melastatin 7 is involved in oestrogen receptor-negative metastatic breast cancer cells migration through its kinase domain. Eur J Cancer 49:36943707. https://doi.org/10.1016/j.ejca.2013.07.008

Guilbert A, Gautier M, Dhennin-Duthille I, Haren N, Sevestre H, Ouadid-Ahidouch H (2009) Evidence that TRPM7 is required for breast cancer cell proliferation. Am J Physiol Cell Physiol 297:C493-502. https://doi.org/10.1152/ajpcell.00624.2008

Hamill OP, Marty A, Neher E, Sakmann B, Sigworth FJ (1981) Improved patch-clamp techniques for high-resolution current recording from cells and cell-free membrane patches. Pflugers Arch 391:85-100. https://doi.org/10.1007/bf00656997

Johnson MD et al (2003) Cadmium mimics the in vivo effects of estrogen in the uterus and mammary gland. Nat Med 9:1081-1084. https://doi.org/10.1038/nm902

Kuipers AJ et al (2018) TRPM7 controls mesenchymal features of breast cancer cells by tensional regulation of SOX4. Biochim Biophys Acta Mol Basis Dis 1864:2409-2419. https://doi. org/10.1016/j.bbadis.2018.04.017

Larsson SC, Orsini N, Wolk A (2015) Urinary cadmium concentration and risk of breast cancer: a systematic review and doseresponse meta-analysis. Am J Epidemiol 182:375-380. https:// doi.org/10.1093/aje/kwv085

Lehmann S et al (2017) Hypoxia induces a HIF-1-dependent transition from collective-to-amoeboid dissemination in epithelial cancer cells. Curr Biol CB 27:392-400. https://doi.org/10.1016/j. cub.2016.11.057

Luongo F, Pietropaolo G, Gautier M, Dhennin-Duthille I, OuadidAhidouch H, Wolf FI, Trapani V (2018) TRPM6 is essential for magnesium uptake and epithelial cell function in the colon. Nutrients. https://doi.org/10.3390/nu10060784

Martineau C, Abed E, Medina G, Jomphe LA, Mantha M, Jumarie C, Moreau R (2010) Involvement of transient receptor potential melastatin-related 7 (TRPM7) channels in cadmium uptake and cytotoxicity in MC3T3-E1 osteoblasts. Toxicol Lett 199:357-363. https://doi.org/10.1016/j.toxlet.2010.09.019

Martinez-Campa C, Alonso-Gonzalez C, Mediavilla MD, Cos S, Gonzalez A, Ramos S, Sanchez-Barcelo EJ (2006) Melatonin inhibits both ER alpha activation and breast cancer cell proliferation induced by a metalloestrogen, cadmium. J Pineal Res 40:291-296. https://doi.org/10.1111/j.1600-079X.2006.00315.x

Meng X et al (2013) TRPM7 mediates breast cancer cell migration and invasion through the MAPK pathway. Cancer Lett 333:96-102. https://doi.org/10.1016/j.canlet.2013.01.031

Middelbeek $\mathbf{J}$ et al (2012) TRPM7 is required for breast tumor cell metastasis. Cancer Res 72:4250-4261. https://doi. org/10.1158/0008-5472.CAN-11-3863

Mittermeier L et al (2019) TRPM7 is the central gatekeeper of intestinal mineral absorption essential for postnatal survival. Proc Natl Acad Sci USA. https://doi.org/10.1073/pnas.1810633116

Monteilh-Zoller MK, Hermosura MC, Nadler MJ, Scharenberg AM, Penner R, Fleig A (2003) TRPM7 provides an ion channel mechanism for cellular entry of trace metal ions. J Gen Physiol 121:49-60
Murai $\mathrm{T}$ et al (2014) Epithelial-to-mesenchymal transition predicts prognosis in clinical gastric cancer. J Surg Oncol 109:684-689. https://doi.org/10.1002/jso.23564

Prakriya M, Lewis RS (2002) Separation and characterization of currents through store-operated CRAC channels and $\mathrm{Mg} 2+$-inhibited cation (MIC) channels. J Gen Physiol 119:487-507

Qu W, Tokar EJ, Kim AJ, Bell MW, Waalkes MP (2012) Chronic cadmium exposure in vitro causes acquisition of multiple tumor cell characteristics in human pancreatic epithelial cells. Environ Health Perspect 120:1265-1271. https://doi.org/10.1289/ ehp. 1205082

Rani A, Kumar A, Lal A, Pant M (2014) Cellular mechanisms of cadmium-induced toxicity: a review. Int J Environ Health Res 24:378-399. https://doi.org/10.1080/09603123.2013.835032

Reichert M et al (2018) Regulation of epithelial plasticity determines metastatic organotropism in pancreatic cancer. Dev Cell 45(696711):e698. https://doi.org/10.1016/j.devcel.2018.05.025

Rybarczyk P et al (2012) Transient receptor potential melastatin-related 7 channel is overexpressed in human pancreatic ductal adenocarcinomas and regulates human pancreatic cancer cell migration. Int $\mathrm{J}$ Cancer 131:E851-861. https://doi.org/10.1002/ijc.27487

Rybarczyk P et al (2017) The transient receptor potential melastatin 7 channel regulates pancreatic cancer cell invasion through the Hsp90alpha/uPA/MMP2 pathway. Neoplasia 19:288-300. https ://doi.org/10.1016/j.neo.2017.01.004

Siewit CL, Gengler B, Vegas E, Puckett R, Louie MC (2010) Cadmium promotes breast cancer cell proliferation by potentiating the interaction between ERalpha and c-Jun. Mol Endocrinol 24:981-992. https://doi.org/10.1210/me.2009-0410

Sun Y, Schaar A, Sukumaran P, Dhasarathy A, Singh BB (2018) TGFbeta-induced epithelial-to-mesenchymal transition in prostate cancer cells is mediated via TRPM7 expression. Mol Carcinogene 57:752-761. https://doi.org/10.1002/mc.22797

Thevenod F (2010) Catch me if you can! Novel aspects of cadmium transport in mammalian cells. Biometals 23:857-875. https://doi. org/10.1007/s10534-010-9309-1

Thevenod F, Fels J, Lee WK, Zarbock R (2019) Channels, transporters and receptors for cadmium and cadmium complexes in eukaryotic cells: myths and facts. Biometals 32:469-489. https://doi. org/10.1007/s10534-019-00176-6

Visser D et al (2013) TRPM7 triggers Ca2+ sparks and invadosome formation in neuroblastoma cells. Cell Calcium 54:404-415. https ://doi.org/10.1016/j.ceca.2013.09.003

Waalkes MP (2003) Cadmium carcinogenesis. Mut Res 533:107-120. https://doi.org/10.1016/j.mrfmmm.2003.07.011

Yee NS, Kazi AA, Li Q, Yang Z, Berg A, Yee RK (2015) Aberrant over-expression of TRPM7 ion channels in pancreatic cancer: required for cancer cell invasion and implicated in tumor growth and metastasis. Biol Open 4:507-514. https://doi.org/10.1242/ bio. 20137088

Zheng X et al (2015) Epithelial-to-mesenchymal transition is dispensable for metastasis but induces chemoresistance in pancreatic cancer. Nature 527:525-530. https://doi.org/10.1038/nature16064

Publisher's Note Springer Nature remains neutral with regard to jurisdictional claims in published maps and institutional affiliations. 